\title{
Chemical composition and antioxidant activities of different parts of Ficus sur
}

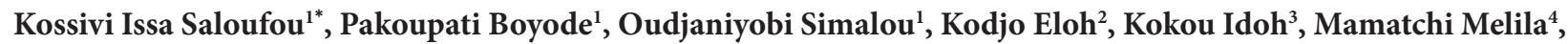 \\ Outéndé Toundou ${ }^{1}$, Kafui Kpegba ${ }^{1}$, Amegnona Agbonon ${ }^{3}$
}

${ }^{1}$ Laboratoire de chimie organique et des substances naturelles (Lab COSNat), Département de Chimie, Faculté Des Sciences, Université de Lomé, 01 BP 1515 Lomé 01, Lomé, TOGO

${ }^{2}$ Department of Life and Environmental Sciences, Unversity of Cagliari, Via Ospedale 72, 09124, Cagliari, Italy

${ }^{3}$ Laboratoire de Physiologie, Pharmacologie et Toxicologie, Faculté des Sciences, Université de Lomé, 01 BP 1515 Lomé 01, Lomé,TOGO

${ }^{4}$ Département de Biochimie, Université de Lomé, 01 BP 1515 Lomé 01, Lomé, TOGO

\section{A R T I C L E I N F O}

Article Type:

Original Article

\section{Article History:}

Received: 10 January 2018

Accepted: 5 June 2018

\section{Keywords:}

Ficus sur

Antioxidant

Phenolic compounds

Flavonoids

HPLC-QTOF-HRMS

\begin{abstract}
A B S T R A C T
Introduction: Ficus sur is a plant widely used in traditional pharmacopoeia in Togo. So, this study aimed the assessment of antioxidant properties and identification of some compounds from the ethanolic extracts of different parts of the plant (leaves, fruits, roots, and barks).

Methods: The phenolic and flavonoid contents of the ethanolic extracts of different organs of Ficus sur were assessed using conventional known methods. The DPPH radical scavenging and the ferric-reducing antioxidant power (FRAP) assays were used to highlight the antioxidant activities. The different extract samples were also analysed by liquid chromatography coupled to a quadrupole-time of flight mass detector (ESI-QTOF).

Results: Total phenolic contents (TPCs) for $1 \mathrm{mg}$ of dry extract ranged from $489.40 \pm 7.48 \mu \mathrm{g}$ GAE (gallic acid equivalents) for the bark to $62.34 \pm 2.66 \mu \mathrm{g}$ GAE for unripe fruits. The bark exhibited the highest flavonoid content, which was closed to $90.20 \pm 3.72 \mu \mathrm{g} \mathrm{QE}$ (quercetin equivalents)/mg of dry extract. The radical scavenging activities of the bark and unripe fruits were $56.50 \pm 0.29$ and $7.3 \pm 0.30 \mu \mathrm{g} \mathrm{QE} / \mathrm{mg}$ of dry extract, respectively. In the same order, the FRAP values of the two organs were $104.57 \pm 4.75$ and $19.61 \pm 0.22 \mu \mathrm{mol} \mathrm{FeSO} \mathrm{Eq}_{4} / \mathrm{mg}$ of dry extract. Many compounds including notoginsenoside R10; 4,5,7-trihydroxyflavan-3-ol; catechin; and boviquinone 4 were identified.

Conclusion: The various organs of Ficus sur are a source of bioactive compounds especially phenolic compounds and flavonoids with antioxidant activity.
\end{abstract}

Implication for health policy/practice/research/medical education:

Well established as source of bioactive compounds, medicinal plants have long been used in treatment of human ailments. The validation of traditional use of medicinal plants can be achieved by screening a collection of extracts for bioactivity using in vitro, in cellulo and even in vivo assays. The results of this work are consistent with the traditional use of the various parts of Ficus sur to cure hepatic pain, cardiovascular and neurodegenerative diseases, cancer, and diabetes. Although the bark extract is more active than the extracts of the other organs, it would be better to use the leaves to preserve the plant, as these contain all the metabolites present in the bark and much more.

Please cite this paper as: Saloufou KI, Boyode P, Simalou O, Eloh K, Idoh K, Melila M, et al. Chemical composition and antioxidant activities of different parts of Ficus sur. J Herbmed Pharmacol. 2018;7(3):185-192. doi: 10.15171/jhp.2018.30.

\section{Introduction}

In recent years, there has been growing interest in alternative therapies by the use of natural products. So, during the last decade, focus has been made on the investigation of phytochemistry of plants for pharmaceutical and nutritional purposes. In Togo, plants are widely used in traditional medicine, especially in the rural areas. Among the plants used in Togolese pharmacopoeia, there is Ficus sur (Moraceae) commonly called "Petit sycamore" in French and "Wild fig" in English. This plant is usually found in tropical and subtropical areas along the rivers. The plant can grow up to 30-35 $\mathrm{m}$ of height while trunk diameter can reach $150 \mathrm{~cm}$ (1). The fruits and leaves of Ficus sur are used as food in the northern Togo. In addition, several medicinal properties have been attributed to various parts of the plant since 
its roots, barks, leaves, and fruits are used to treat, relieve and heal several pathologies. Indeed, the roots are braised and crushed with grilled corn cobs, then the sieved are used against female infertility. The crushed and macerated fruits in water are used for the care of women during childbirth and after delivery (promotion of lactation) (1). The beverage obtained by decoction after mixing roots and leafy twigs is used to treat eczema (1). Decocted trunk bark is used against amenorrhea, dysentery, hepatic, and cardiovascular pain (2-4).

It is known that oxidative stress is involved in many inflammatory processes related to chronic diseases such as cardiac dysfunction, neurodegenerative diseases or diabetes (5). Indeed, a large number of phenolic compounds such as flavonoids, isoflavones, and phenolic acids have shown antioxidant activity (6-9). Moreover, the benefits of phenolic antioxidant compounds from plants in prevention of chronic diseases have been reported $(10,11)$.

In our preliminary work on this plant, two bioactive phytosterols were identified in the cyclohexanic extract of the leaves (12). The aim of the current work was to assess the antioxidant properties, the total phenolic and flavonoid contents, and then identify some more compounds from various organs of this medicinal plant.

\section{Materials and Methods}

Plant material

The leaves, roots, bark, ripe and unripe fruits of Ficus sur were harvested at north latitude $11^{\circ} 05^{\prime} 31^{\prime \prime}$ and east longitude $00^{\circ} 19^{\prime} 38^{\prime \prime}$ in the northern region of Togo (Dapaong). Samples were dried at room temperature inside the laboratory and then reduced to a fine powder using a mill (Thomas Scientific Laboratory Mill Model 4, USA) with a sieve of $1 \mathrm{~mm}$ porosity. The extracts were obtained by macerating in ethanol $\left(95^{\circ}\right)$ for 72 hours. After filtration, the solvent was evaporated under reduced pressure at $30^{\circ} \mathrm{C}$.

\section{Antioxidant activity}

The antioxidant activities of the extracts were evaluated by the DPPH radical-scavenging activity and the ferricreducing antioxidant power (FRAP).

Determination of DPPH radical-scavenging activity The method, inspired by the works of Molyneux (13) and Constantin et al (14), is based on the reduction of the violet $\mathrm{DPPH}^{\bullet}$ radical by an $\mathrm{H}$ atom donor $(\mathrm{AH})$ leading to the formation of the colorless 2,2-diphenyl-1-picrylhydrazine $(\mathrm{DPPH}-\mathrm{H})$ and the radical $\left(\mathrm{A}^{\bullet}\right)$ according to the following equation: $\mathrm{DPPH}^{\bullet}+\mathrm{AH} \rightarrow \mathrm{DPPH}-\mathrm{H}+\mathrm{A}^{\bullet}$

One hundred microliters $(100 \mu \mathrm{L})$ of each extract or standard methanolic solutions was mixed and vortexed with a $2 \mathrm{~mL}$ methanolic solution of DPPH $\left(10^{-4} \mathrm{M}\right)$. Only methanol was used as extract solution in the control sample. The fading of the purple free radical DPPH solution by effect of the extracts was measured at $517 \mathrm{~nm}$ using a Genesys 10S UV-Vis spectrophotometer (USA), after incubating samples at room temperature in the dark for 30 minutes. A quercetin calibration curve was established for concentrations ranging from 0 to $30 \mu \mathrm{g} / \mathrm{mL}$. Results were expressed in mg of quercetin equivalents/g of dry extract (mg QE/g).

Determination of ferric-reducing antioxidant power The FRAP assay consists in reducing the intense blue tripyridyltriazine-ferric complex ( $\left.\mathrm{Fe}^{3+}-\mathrm{TPTZ}\right)$. At $\mathrm{pH}$ 3.5, the $\mathrm{Fe}^{3+}$-TPTZ complex is added to the sample whose antioxidant compounds have effect to reduce this complex into its reduced form $\mathrm{Fe}^{2+}$-TPTZ. The test was carried out according to the method described by Nair et al (15). In tubes containing $300 \mu \mathrm{L}$ of freshly prepared FRAP solution (25 mL of acetate buffer, $2.5 \mathrm{~mL}$ of $10 \mathrm{mM} \mathrm{Fe} \mathrm{F}^{3+}$-TPTZ in $40 \mathrm{mM} \mathrm{HCl}$ and $2.5 \mathrm{~mL}$ of $\left.20 \mathrm{mM} \mathrm{FeCl}_{3}, 6 \mathrm{H}_{2} \mathrm{O}\right), 30 \mu \mathrm{L}$ of distilled water and $10 \mu \mathrm{L}$ of sample were added. The change in absorbance from the red to blue was followed at $593 \mathrm{~nm}$ after a process of 10 minutes of incubation. A calibration curve was established from a concentration range of 0 to $2000 \mu \mathrm{M}$ of iron sulphate $\left(\mathrm{FeSO}_{4}, 7 \mathrm{H}_{2} \mathrm{O}\right)$ solution dissolved in methanol (blank). The obtained results were expressed in $\mu \mathrm{mol}$ of $\mathrm{FeSO}_{4}$ equivalents/mg of dry extract.

Phytochemical profiles of the different organs of Ficus sur An initial rapid screening of molecular families present in the different organ extracts was done using specific reagents and procedures described in the literature (16-18).

Determination of total phenolic content

The colorimetric method developed by Singleton et al (19) and slightly modified by Al-Farsi et al (20) was used. An aliquot of $100 \mu \mathrm{L}$ of each extract at $1 \mathrm{mg} / \mathrm{mL}$ was mixed with $750 \mu \mathrm{L}$ of Folin-Ciocalteu reagent diluted up to $1 / 10$. After 5 minutes of incubation at $25^{\circ} \mathrm{C}, 750 \mu \mathrm{L}$ of $\mathrm{Na}_{2} \mathrm{CO}_{3}$ aqueous solution (20\%) was added. The obtained mixture was incubated for 90 minutes in the dark and the change in absorbance was followed at $\lambda=765 \mathrm{~nm}$. The extract was substituted by distilled water for blank. Gallic acid at different concentrations $(0-500 \mu \mathrm{g} / \mathrm{mL})$ was used as standard and the results were expressed in $\mu \mathrm{g}$ of gallic acid equivalents per milligram of dry extract ( $\mu \mathrm{g}$ of GAE/ $\mathrm{mg}$ of dry extract) by extrapolating the calibration line (y $\left.=0.005018 \mathrm{x}+0.055190, \mathrm{R}^{2}=0.9925\right)$ obtained from the different concentrations of gallic acid. The Genesys $10 \mathrm{~S}$ UV-Vis Spectrophotometer, USA was used.

Determination of flavonoid content

The total flavonoid contents (TFCs) of the extracts were estimated via the colorimetric aluminum trichloride 
$\left(\mathrm{AlCl}_{3}\right)$ method described by Kim et al (21). One hundred microliters $(100 \mu \mathrm{L})$ of ethanolic extracts solution was added to $400 \mu \mathrm{L}$ of distilled water. Thirty microliters (30 $\mu \mathrm{L})$ of a $5 \%$ sodium nitrite $\left(\mathrm{NaNO}_{2}\right)$ solution was added to the former mixture. After 5 minutes of incubation at room temperature, $20 \mu \mathrm{L}$ of a $10 \%$ aqueous solution of $\mathrm{AlCl}_{3}$ was added. Finally, $200 \mu \mathrm{L}$ of a $\mathrm{Na}_{2} \mathrm{CO}_{3}$ aqueous solution (1M) and 5 minutes later, $250 \mu \mathrm{L}$ of distilled water (blank) were added, successively. The whole mixture was vortexed and the absorbance was measured directly with UV-Vis spectrophotometer (Genesys $10 \mathrm{~S}$ UV-Vis Spectrophotometer, USA) at $\lambda=510 \mathrm{~nm}$. The concentration of total flavonoids was deduced from the calibration curve established with quercetin (0-500 $\mu \mathrm{g} /$ $\mathrm{mL}$ ) and the results were expressed in $\mu \mathrm{g}$ quercetin equivalents/mg of dry extract ( $\mu \mathrm{g} \mathrm{EQ} / \mathrm{mg}$ of extract).

\section{Statistical analysis}

Results were analyzed statistically using the OriginPro 9.0 software. Data were expressed as means \pm standard deviation (SD) of experiments performed in triplicate. One-way analysis of variance (ANOVA), principal component analysis (PCA) and Pearson correlation coefficient $(\rho)$ were used to evaluate and correlate the results with each other. Differences with $P$ values less than 0.05 were considered significant.

\section{HPLC-ESI ${ }^{+}$-QTOF-HRMS analysis}

A methanolic solution $(1000 \mu \mathrm{g} / \mathrm{mL})$ was prepared from the ethanolic extracts of different organs. The chromatographic analysis for the separation of the compounds was carried out in reverse phase on an Agilent series 1200 HPLC system equipped with a C18 column from Microchip Technology (Agilent, Zorbax 300 SB-C18, 5 m, 43 mm,
$75 \mu \mathrm{m})$. An Agilent 6530 quadrupole - time of flight (QTOF) mass detector (Agilent Technologies, Santa Clara, Calif., USA) coupled to an electrospray ionizer (ESI) was used. Chromatographic conditions were as follows: flow rate: $0.4 \mu \mathrm{L} . \mathrm{min}^{-1}$; solvent $\mathrm{A}: 0.1 \%$ formic acid in water; solvent B: $0.1 \%$ formic acid in methanol. The solvent gradient $(\mathrm{v} / \mathrm{v})$ was generated starting from $20 \% \mathrm{~B}$ and reaching $100 \%$ B in 10 minutes and maintaining at $100 \%$ $\mathrm{B}$ for 10 minutes for a total run of $20 \mathrm{~min}$. Two microliters of the samples were analyzed by ESI in positive mode. Mass spectral data were acquired in the range m/z 1001500 , with an acquisition rate of 1.35 spectra. $\mathrm{s}^{-1}$, averaging 10000 transients. The source parameters were adjusted as follows: drying gas temperature $250^{\circ} \mathrm{C}$, drying gas flow rate $5 \mathrm{~L} \cdot \mathrm{min}^{-1}$, nebuliser pressure $45 \mathrm{psi}$ and fragmentor voltage $150 \mathrm{~V}$. Data acquisition and processing were done by Agilent MassHunter Workstation Acquisition software v. B.02.00. The METLIN database (https://metlin.scripps. edu/index.php) was used to predict plausible structures of detected metabolites.

\section{Results}

Evaluation of antioxidant activity

To investigate the antioxidant activity of the various organs of Ficus sur, two in vitro assays were used, the DPPH radical scavenging and the FRAP assays. Results are resumed in Figure 1. The bark extract had the best $\mathrm{DPPH}$ radical scavenging activity closed to $56.50 \pm 0.29$ $\mu \mathrm{g} \mathrm{QE} / \mathrm{mg}$ of dry extract; the ripe fruit extract being the least active with an activity of $7.3 \pm 0.30 \mu \mathrm{g} Q E / m g$ of dry extract. The evaluation of the ferric ion reduction power yielded FRAP values ranging from $104.57 \pm 4.75 \mu \mathrm{mol}$ $\mathrm{FeSO}_{4} \mathrm{Eq} / \mathrm{mg}$ dry extract for the bark to $19.61 \pm 0.22 \mu \mathrm{mol}$ $\mathrm{FeSO}_{4} \mathrm{Eq} / \mathrm{mg}$ of dry extract for ripe fruits.

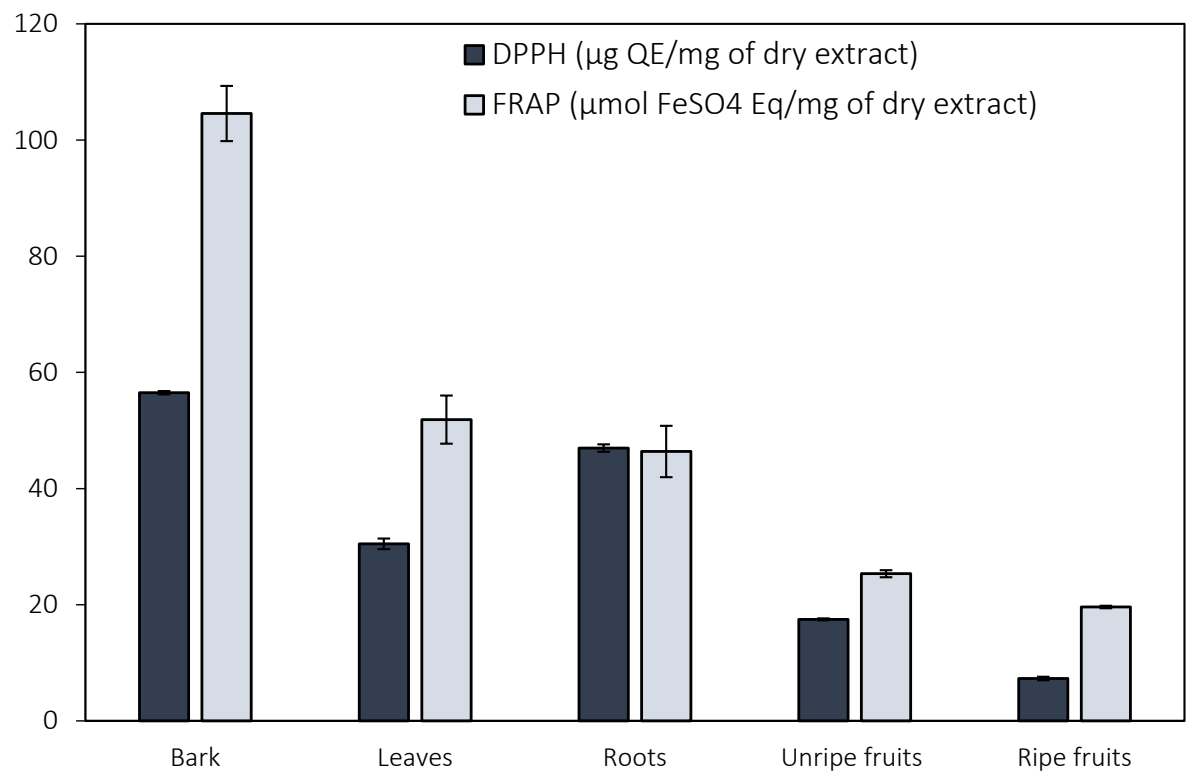

Figure 1. Antioxidant abilities in $\mu \mathrm{g}$ QE (quercetin equivalents)/mg of dry extract (for the DPPH radical scavenging assay) and in $\mu$ mol $\mathrm{FeSO}_{4} \mathrm{Eq} / \mathrm{mg}$ of dry extract (for the FRAP assay). Values are expressed as mean $\pm \mathrm{SEM} ; \mathrm{n}=3$. 
Table 1. Phytochemical analysis of the various organs of Ficus sur

\begin{tabular}{|c|c|c|c|c|c|}
\hline Phyto-chemicals & Ripe fruits & Unripe fruits & Leaves & Bark & Root \\
\hline Alkaloids & + & + & + & + & + \\
\hline Flavonoids & + & + & + & + & + \\
\hline Saponosides & + & + & + & + & + \\
\hline Quinones & - & - & - & - & - \\
\hline Glycosides & + & + & + & + & + \\
\hline Tannins & + & + & + & + & + \\
\hline Sterols and terpenoid & + & + & + & + & + \\
\hline Anthocyanins & + & + & + & + & + \\
\hline
\end{tabular}

$(+)=$ present $;(-)=$ absent.

\section{Phytochemical screening}

The phytochemical screening revealed the presence of alkaloids, flavonoids, saponosides, glycosides, anthocyanins, tannins, sterols, and terpenoid in the various organs of Ficus sur (Table 1).

Total phenolic content

Figure 2 reports the different values of total phenolic contents (TPCs) of the various organs of Ficus sur. For 1 $\mathrm{mg}$ of the dry extracts, the TPC ranged from $489.40 \pm 7.48$ $\mu \mathrm{g}$ GAE for the bark to $62.34 \pm 2,66 \mu \mathrm{g}$ GAE for unripe fruits. For the other organs, the values are as follows: $177.79 \pm 3.29 \mu \mathrm{g}$ GAE for the roots, $84.86 \pm 15.06 \mu \mathrm{g} \mathrm{GAE}$ for the ripe fruits and $66.06 \pm 7.44 \mu \mathrm{g}$ GAE for leaves.

Total flavonoid content

The TFCs of the various organs of Ficus sur are reported in Figure 2. The bark had the highest flavonoids content, $90.20 \pm 3.72 \mu \mathrm{g} \mathrm{QE} / \mathrm{mg}$ of dry extract. This was followed by ripe fruit $(78.07 \pm 10.23 \mu \mathrm{g} \mathrm{QE} / \mathrm{mg}$ of dry extract), roots $(48.55 \pm 3.19 \mu \mathrm{g} \mathrm{QE} / \mathrm{mg}$ of dry extract), unripe fruits $(31.57 \pm 5.72 \mu \mathrm{g} \mathrm{QE} / \mathrm{mg}$ dry extract) and leaves (27.06 \pm

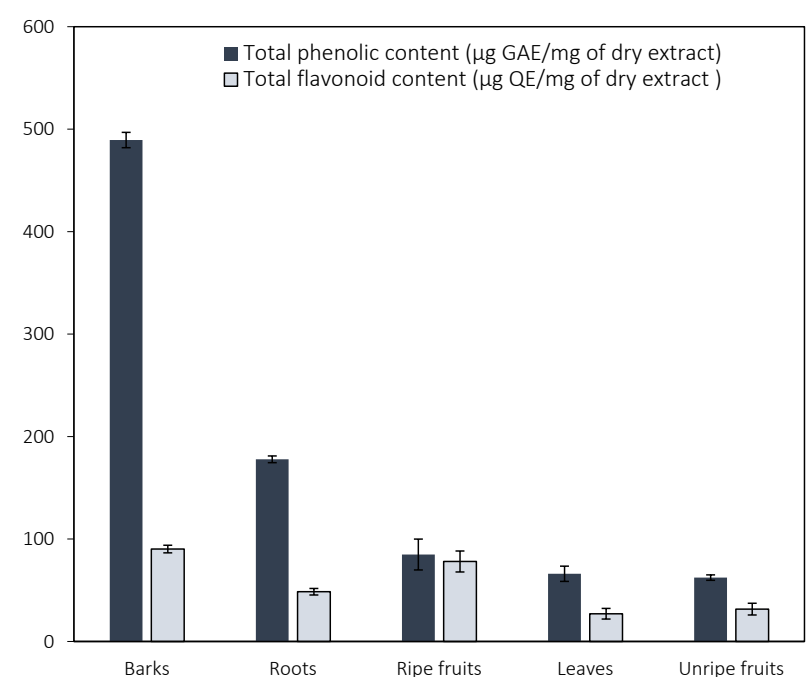

Figure 2. Total phenolic and flavonoid content of extracts from different organs of Ficus sur. Values are expressed as mean \pm SEM; $\mathrm{n}=3$.
$5.19 \mu \mathrm{g} \mathrm{QE} / \mathrm{mg}$ of dry extract).

Results of the descriptive statistical analyses

Figure 3 shows the principal component analysis (PCA) carried out taking into account the different parameters (TFC, TPC, FRAP and DPPH). The Pearson correlation coefficients $(\rho)$ determined in order to quantify correlation between those parameters are resumed in Table 2 .

Identification of the main compounds of the various extracts

The HPLC analysis of each tested extract yielded the chromatograms which are shown in Figure 4. The comparative chromatographic profile of roots, barks, leaves, and ripe fruit shows (Figure 4), on the one hand, common peaks to all the four extracts (peaks 1-23) and on the other hands, some peaks that discriminate different organs (peaks a-q). This comparison shows that the root extract has the simplest chromatographic profile, followed by barks, leaves, and finally by fruits which exhibit complex profile.

The ESI ${ }^{+}$-QTOF-HRMS analysis offered the possibility to determine the exact masses of the different compounds detected. Many characteristics of the different compounds identified are summarized in Tables 3 and 4.

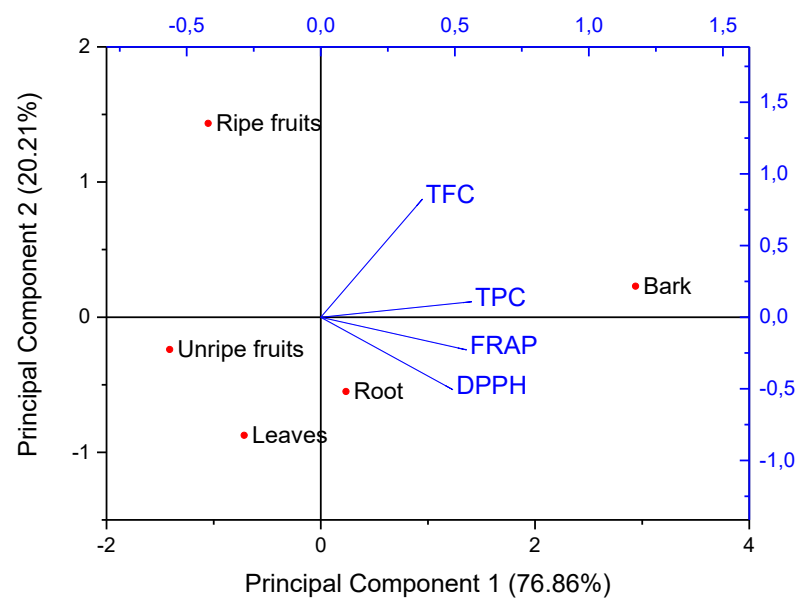

Figure 3. Comparison of the different organs by principal component analysis. 
Table 2. Correlation matrix between DPPH, FRAP, TFC and TPC

\begin{tabular}{lcccc}
\hline & DPPH & TPC & TFC & FRAP \\
\hline DPPH & 1 & 0.79994 & 0.25466 & 0.8747 \\
TPC & 0.79994 & 1 & 0.72076 \\
TFC & 0.25466 & 0.72076 & 1 & 0.92075 \\
FRAP & 0.8747 & 0.92075 & 0.46917 & 1 \\
\hline
\end{tabular}

\section{Discussion}

All extracts from the various organs of Ficus sur showed antioxidant activities considering the two assays: DPPH and FRAP. Indeed, the different extracts exhibited positive effect to the total phenolics and flavonoids contents. The PCA allowed a better understanding of the relative behavior of the different parameters studied. In fact, the determination of the Pearson correlation coefficient between FRAP and DPPH $(\rho=0.8747)$ indicated that the two methods of assessing the antioxidant activity progress together and could be complementary. Moreover, the TPC is strongly correlated with the FRAP values ( $\rho=$ $0.92075)$ and DPPH values $(\rho=0.79994)$. The similar observations were made by Michel et al (22). Flavonoids are a subclass of phenolic compounds recognized as an important source of antioxidants (23). In this work, although the TFCs are well correlated with those of the total phenolic compounds ( $\rho=0.72076)$, the antioxidant activity is very weakly related to the TFCs; the coefficients being 0.25466 between the TFC and the DPPH values and 0.46917 with those of the FRAP. This weak correlation could be explained by the non-specificity of the flavonoid assay method. Indeed, as illustrated by Cornard and Merlin (24), quercetin is able to form stable compounds in the presence of aluminum chloride since three different complexation sites (3-hydroxy-4-keto, 5-hydroxy-4-keto, $3^{\prime}, 4^{\prime}$-o-diphenolic) exist in its structure. The extracts showing positive responses to this assay might contain derivatives of quercetin and more generally flavonoids. However, it should be noted that some terpene compounds with adjacent hydroxyl, acidic or coumaryl groups that favour the complexation of aluminum may also respond

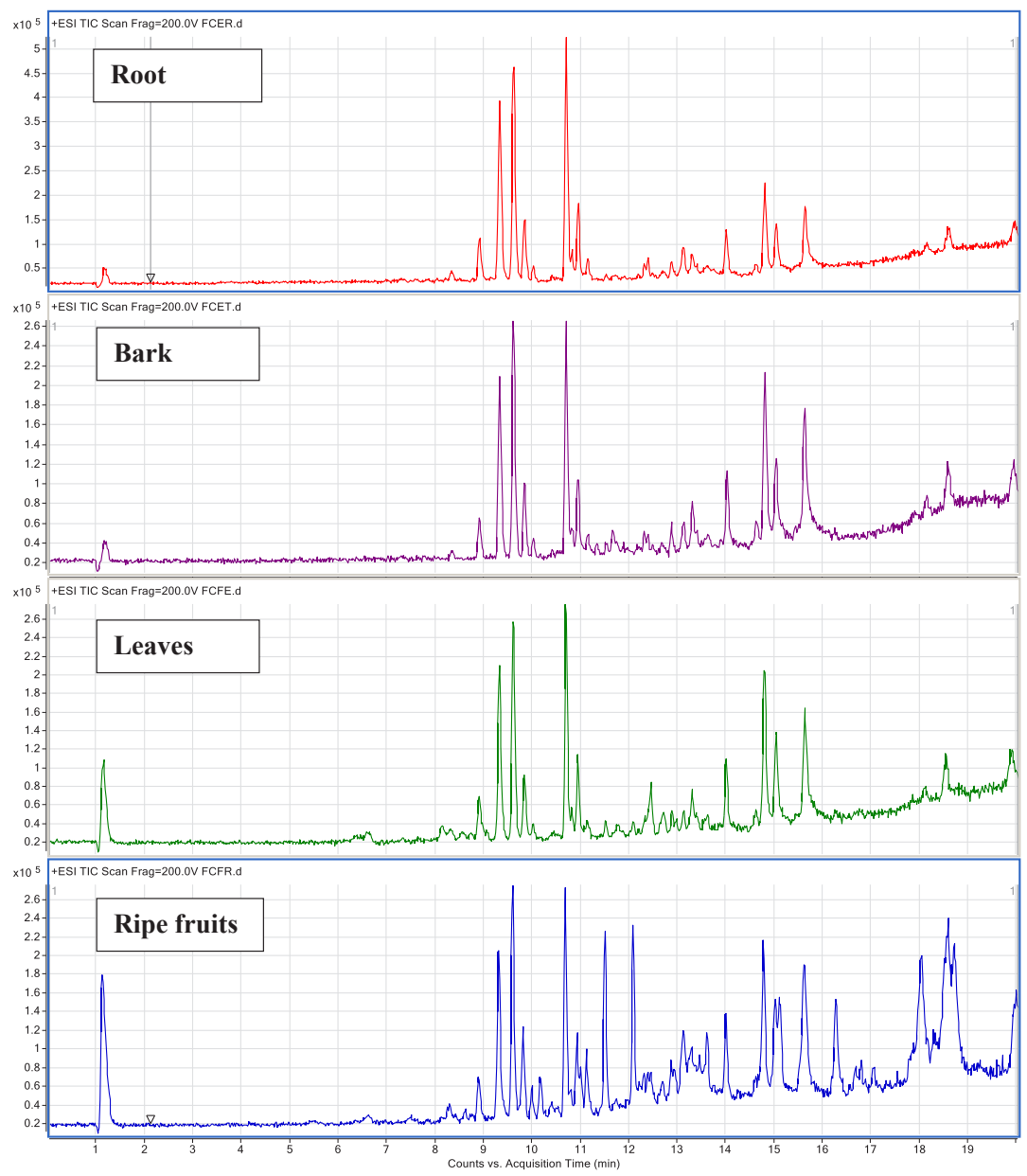

Figure 4. Chromatographic profiles of the extracts from various organs. 
Table 3. Characteristics of the common compounds of the extracts of the various organs of Ficus sur

\begin{tabular}{|c|c|c|c|c|c|}
\hline Peak & RT (min) & $\begin{array}{c}{[\mathrm{M}+\mathrm{H}]^{+}} \\
\mathrm{m} / \mathrm{z}\end{array}$ & Proposed molecular formula & Proposed compound identification & Class \\
\hline 1 & 8.31 & 453.3470 & $\mathrm{C}_{20} \mathrm{H}_{36} \mathrm{O}_{11}$ & 2-Cyclohexyl-1-ethyl- $\beta$-D-maltoside & Glycoside \\
\hline 2 & 8.89 & 567.4323 & N.I. & - & - \\
\hline 3 & 9.28 & 555.3575 & $\mathrm{C}_{30} \mathrm{H}_{50} \mathrm{O}_{9}$ & Notoginsenoside R10 & Glycoside \\
\hline 4 & 9.60 & 396.8035 & N.I. & - & - \\
\hline 5 & 9.81 & 453.8481 & N.I. & - & - \\
\hline 6 & 9.99 & 509.8878 & N.I. & - & - \\
\hline 7 & 10.69 & 275.2768 & $\mathrm{C}_{15} \mathrm{H}_{14} \mathrm{O}_{5}$ & 4,,5,7-trihydroxyflavan-3-ol & Flavonoid \\
\hline 8 & 10.93 & 291.2711 & $\mathrm{C}_{15} \mathrm{H}_{14} \mathrm{O}_{6}$ & Catechin or isomer & Flavonoid \\
\hline 9 & 11.13 & 304.3010 & $\mathrm{C}_{21} \mathrm{H}_{37} \mathrm{~N}$ & 3,5-dipentyl-2-hexyl-pyridine & Alkaloid \\
\hline 10 & 12.35 & 579.2985 & N.I. & - & - \\
\hline 11 & 12.69 & 277.2176 & $\mathrm{C}_{18} \mathrm{H}_{28} \mathrm{O}_{2}$ & $\alpha$-Parinaric acid & Fatty acid \\
\hline 12 & 12.86 & 425.2159 & $\mathrm{C}_{22} \mathrm{H}_{32} \mathrm{O}_{8}$ & Dihydrovaltrate & Fatty acid \\
\hline 13 & 13.10 & 502.3760 & N.I. & - & - \\
\hline \multirow{2}{*}{14} & 13.28 & 470.2553 & N.I. & - & - \\
\hline & 13.29 & 491.1869 & N.I. & - & - \\
\hline 15 & 13.60 & 637.3068 & N.I. & - & - \\
\hline \multirow{2}{*}{16} & 13.98 & 257.2486 & $\mathrm{C}_{16} \mathrm{H}_{32} \mathrm{O}_{2}$ & Palmitic acid & Fatty acid \\
\hline & 13.99 & 353.2673 & $\mathrm{C}_{21} \mathrm{H}_{36} \mathrm{O}_{4}$ & Ceriporic acid C & Fatty acid \\
\hline 17 & 14.66 & 522.5984 & N.I. & - & - \\
\hline \multirow{2}{*}{18} & 14.78 & 285.2799 & $\mathrm{C}_{18} \mathrm{H}_{36} \mathrm{O}_{2}$ & Stearic acid or isomer & Fatty acid \\
\hline & 14.78 & 381.2989 & $\mathrm{C}_{23} \mathrm{H}_{40} \mathrm{O}_{4}$ & Persine or isomer & Fatty acid \\
\hline 19 & 15.02 & 413.2679 & $\mathrm{C}_{26} \mathrm{H}_{36} \mathrm{O}_{4}$ & Boviquinone 4 & terpenoid \\
\hline 20 & 15.42 & 437.2887 & $\mathrm{C}_{25} \mathrm{H}_{40} \mathrm{O}_{6}$ & Salvisyriacolide & terpenoid \\
\hline 21 & 18.16 & 520.4382 & N.I. & - & - \\
\hline 22 & 18.59 & 685.4381 & N.I. & - & - \\
\hline 23 & 19.9 & 569.4346 & $\mathrm{C}_{40} \mathrm{H}_{56} \mathrm{O}_{2}$ & Lutein & Carotenoid \\
\hline
\end{tabular}

N.I. = Not Identified.

Table 4. Characteristics of compounds discriminating extracts of the various organs of Ficus sur

\begin{tabular}{|c|c|c|c|c|c|c|}
\hline Peak & $\mathrm{RT}$ (min) & $\begin{array}{l}{[\mathrm{M}+\mathrm{H}]^{+}} \\
\mathrm{m} / \mathrm{z}\end{array}$ & $\begin{array}{l}\text { Proposed molecular } \\
\text { formula }\end{array}$ & Proposed compound identification & Class & Organ \\
\hline a & 6.35 & 377.0863 & $\mathrm{C}_{18} \mathrm{H}_{16} \mathrm{O}_{9}$ & 5,7,3',6'-Tetrahydroxy-6,8,2'-trimethoxyflavone & Flavonoid & Le \\
\hline$b$ & 6.63 & 235.0612 & $\mathrm{C}_{12} \mathrm{H}_{10} \mathrm{O}_{5}$ & Armillarisin A or isomer & Coumarin & Le, $\mathrm{Fr}$ \\
\hline c & 8.18 & 608.3866 & N.I. & - & - & Le \\
\hline$d$ & 8.66 & 393.1897 & N.I. & - & - & Le, $\mathrm{Fr}$ \\
\hline e & 8.76 & 481.1690 & N.I. & - & - & Le \\
\hline$f$ & 10.16 & 293.0432 & N.I. & - & - & $\mathrm{Fr}$ \\
\hline g & 11.25 & 479.1722 & N.I. & - & - & $\mathrm{Ba}$ \\
\hline h & 11.49 & 415.2132 & $\mathrm{C}_{24} \mathrm{H}_{30} \mathrm{O}_{6}$ & Armillarine & Sesquiterpene aryl ester & $\mathrm{Ba}, \mathrm{Le}, \mathrm{Fr}$ \\
\hline i & 11.76 & 288.2570 & N.I. & - & - & $\mathrm{Ba}$, Le, Fr \\
\hline j & 12.07 & 452.3259 & $\mathrm{C}_{28} \mathrm{H}_{41} \mathrm{~N}_{3} \mathrm{O}_{2}$ & Teleocidin B1 or isomer & Alkaloid & Le, $\mathrm{Fr}$ \\
\hline k & 13.37 & 468.3925 & $\mathrm{C}_{30} \mathrm{H}_{49} \mathrm{~N}_{3} \mathrm{O}$ & Lucidine B & Alkaloid & $\mathrm{Fr}$ \\
\hline e & 16.25 & 484.3889 & N.I. & - & - & $\mathrm{Fr}$ \\
\hline $\mathrm{m}$ & 16.47 & 469.3321 & $\mathrm{C}_{30} \mathrm{H}_{44} \mathrm{O}_{4}$ & Uralenolide & Terpenoid & $\mathrm{Fr}$ \\
\hline$n$ & 16.77 & 429.3746 & $\mathrm{C}_{29} \mathrm{H}_{48} \mathrm{O}_{2}$ & Saringosterol & Sterol & $\mathrm{Fr}$ \\
\hline o & 17.11 & 427.3940 & $\mathrm{C}_{30} \mathrm{H}_{50} \mathrm{O}$ & alpha-amyrin or isomer & terpenoid & $\mathrm{Fr}$ \\
\hline $\mathrm{p}$ & 18.16 & 520.4382 & N.I. & - & - & $\mathrm{Fr}$ \\
\hline q & 18.62 & 703.4176 & N.I. & - & - & $\mathrm{Fr}$ \\
\hline
\end{tabular}


positively to this assay (25).

Figure 3 provides an excellent comparison of the various organs studied. In that figure one may notice the eccentricity of two organs: on the one hand, the bark which seems more antioxidant and richer in phenolic compounds and on the other hand the ripe fruits with less antioxidant activity and less rich in phenolic compounds. Unripe fruits, leaves and roots have more or less similar behaviour in relation to the parameters studied. This trend is confirmed by the one-way ANOVA. In fact, with the DPPH radical scavenging assay, the bark extract is significantly more antiradical $(P<0.0001)$ than the extracts of the other organs. All antiradical activities are significantly different from each other and decrease in the following order: bark, roots, leaves, unripe fruits, ripe fruits. This order is almost confirmed by the FRAP test, except that the leaves are significantly more active than the root. Similarly, for phenolic compound contents, the bark is significantly richer in those metabolites $(P<0.0001)$. The HPLC-ESI ${ }^{+}$-QTOF-HRMS analysis provided important information on the nature of the metabolites contained in the various extracts. Positive ionization yielded proton molecular ions $[\mathrm{M}+\mathrm{H}]^{+}$and the approximate value of the mass of each $[\mathrm{M}+\mathrm{H}]^{+}$ion was given with the corresponding molecular structure in the METLIN database. Mass analysis showed more than one compound for some peaks (peaks 14 and 18), demonstrating that the problem of coelution of some compounds in HPLC can be solved by mass spectrometry. Based on the $[\mathrm{M}+\mathrm{H}]^{+}$ quasi-molecular ions provided by the high-resolution mass spectra, some common compounds from the various extracts might be notoginsenoside R10 (peak 3) and 4,5,7-trihydroxyflavan-3-ol (peak 7). According to previous studies, the latter compound (a flavonoid), has been identified in Ficus sur (26). In the present work, other major compounds such as catechin, palmitic acid, saringosterol and $\alpha$-amyrin have been identified. The presence of some of these compounds in Ficus sur extracts has been previously reported $(27,28)$.

\section{Conclusion}

This study shows that the different organs of Ficus sur constitute an important source of phenolic compounds and flavonoids. The immature fruit extract which is poor in phenolic compounds contains $62.34 \pm 2.66 \mu \mathrm{g}$ GAE for $1 \mathrm{mg}$ of dry extract while the extract of the bark (the most active) contains $489.40 \pm 7.48 \mu \mathrm{g}$ GAE/mg dry extract. The correlation assessment shows that about $72 \%$ of the phenolic compounds found in the Ficus sur would be flavonoids. Moreover, the FRAP technique and the inhibition of the DPPH radical confirmed that the various organs of Ficus sur contain metabolites with potential antioxidant activity. Above all, statistical analyses such as PCA and ANOVA showed that the bark is the organ that contains both the most important phenolic content and presents the best antioxidant activity. The bark of Ficus sur would therefore be a natural source for the search for active ingredients against cardiovascular diseases, neurodegenerative diseases, cancer, and diabetes.

\section{Acknowledgement}

The authors thank Professor Pierluigi Caboni for his help concerning the use of the HPLC-ESI-HRMS device.

\section{Authors' contributions}

$\mathrm{KIS}, \mathrm{PB}, \mathrm{OS}$ and $\mathrm{MM}$ conceived and designed the experiments; KIS, KE, KI, performed the experiments; KIS, OS, KE, KI and OT analysed the data; PB, OS, KK and AA supervised the experiments; all authors contributed to the writing of the manuscript and confirmed publication of the final version.

\section{Conflict of interests}

The authors have no conflicts of interest.

\section{Ethical considerations}

Ethical consideration has been completely observed by the authors.

\section{Funding/Support}

This research was financially supported by Université de Lomé (Togo) and Agence Universitaire de la Francophonie/ Bureau Afrique de l'Ouest.

\section{References}

1. Malgras D. Arbres et arbustes guérisseurs des savanes maliennes. Paris: Karthala \& ACCT; 1992.

2. Nadel H, Frank JH, Knight RJ. Escapees and Accomplices: The Naturalization of Exotic Ficus and Their Associated Faunas in Florida. Fla Entomol. 1992;75(1):29-38. doi: $10.2307 / 3495478$

3. Kapoor M, Jasani N, Acharya N, Acharya S, Kumar V. Phytopharmacological evaluation and anti-asthmatic activity of Ficus religiosa leaves. Asian Pac J Trop Med. 2011;4(8):642-4. doi: 10.1016/s1995-7645(11)60163-6.

4. Amandeep K, Rana AC, Vineeta T, Ramica S, Sunil K. Review on ethanomedicinal and pharmacological properties of Ficus religiosa. J Appl Pharm Sci. 2011;1(8):611.

5. Kazemi S, Shirzad H, Rafieian-Kopaei M. Recent findings in molecular basis of inflammation and anti-inflammatory plants. Curr Pharm Des. 2018. doi: 10.2174/138161282466 6180403122003.

6. Fattouch S, Caboni P, Coroneo V, Tuberoso CI, Angioni A, Dessi S, et al. Antimicrobial activity of Tunisian quince (Cydonia oblonga Miller) pulp and peel polyphenolic extracts. J Agric Food Chem. 2007;55(3):963-9. doi: 10.1021/jf062614e.

7. Cai Y, Luo Q, Sun M, Corke H. Antioxidant activity and phenolic compounds of 112 traditional Chinese medicinal plants associated with anticancer. Life Sci. 2004;74(17):215784. doi: 10.1016/j.lfs.2003.09.047.

8. Balasundram N, Sundram K, Samman S. Phenolic 
compounds in plants and agri-industrial by-products: Antioxidant activity, occurrence, and potential uses. Food Chem. 2006;99(1):191-203. doi: 10.1016/j. foodchem.2005.07.042.

9. Zheng W, Wang SY. Antioxidant activity and phenolic compounds in selected herbs. J Agric Food Chem. 2001;49(11):5165-70. doi: 10.1021/jf010697n.

10. Sies H, Hollman PC, Grune T, Stahl W, Biesalski HK, Williamson G. Protection by flavanol-rich foods against vascular dysfunction and oxidative damage: 27th Hohenheim Consensus Conference. Adv Nutr. 2012;3(2):217-21. doi: 10.3945/an.111.001578.

11. Watson RR, Preedy VR, Zibadi S. Polyphenols in human health and disease. London: Academic Press; 2013.

12. Saloufou KI, Boyode PB, Simalou O, Eloh K, Melila $\mathrm{M}$, Kpegba $\mathrm{K}$, et al. Identification de deux phytosterols biologiquement actifs de lextrait cyclohexanique des feuilles de Ficus sur (Moraceae). Int J Biol Chem Sci. 2017;11(5):2510-20. doi: 10.4314/ijbcs.v11i5.44.

13. Molyneux $P$. The use of the stable free radical diphenylpicrylhydrazyl (DPPH) for estimating antioxidant activity. Songklanakarin J Sci Technol. 2004;26(2):211-9.

14. Dabire C, Nebie RHC, Belanger A, Nacro M, Sib FS. Effet du séchage de la matière végétale sur la composition chimique de l'huile essentielle et l'activité antioxydante d'extraits de Ocimum basilicum L. Int J Biol Chem Sci. 2011;5(3):108295. doi: 10.4314/ijbcs.v5i3.72218.

15. Nair VD, Dairam A, Agbonon A, Arnason JT, Foster BC, Kanfer I. Investigation of the Antioxidant Activity of African Potato (Hypoxis hemerocallidea). J Agric Food Chem. 2007;55(5):1707-11. doi: 10.1021/jf0619838.

16. Evans WC. Trease and Evans' Pharmacognosy. London: Saunders Elsevier; 2009.

17. Dohou N, Yamni K, Tahrouch S, Idrisi Hassani LM, Badoc A, Gmira N. Screening phytochimique d'une endémique ibero-marocaine, Thymelaea lythroides. Bull Soc Pharm Bord. 2003;142:61-78.

18. N'Guessan K, Kadja B, Zirihi G, Traore D, Ake-Assi L. Screening phytochimique de quelques plantes médicinales ivoiriennes utilisées en pays Krobou (Agboville, Côted'Ivoire). Sci Nat. 2009;6(1):1-15. doi: 10.4314/scinat. v6i1.48575.

19. Singleton VL, Orthofer R, Lamuela-Raventos RM. Analysis of total phenols and other oxidation substractes and antioxidants by means of Folin Ciocaleu Reagent. Methods Enzymol. 1999;299:152-78. doi: 10.1016/S00766879(99)99017-1.

20. Al-Farsi M, Alasalvar C, Morris A, Baron M, Shahidi F. Comparison of antioxidant activity, anthocyanins, carotenoids, and phenolics of three native fresh and sundried date (Phoenix dactylifera L.) varieties grown in Oman. J Agric Food Chem. 2005;53(19):7592-9. doi: 10.1021/ jf050579q.

21. Kim DO, Jeong SW, Lee CY. Antioxidant capacity of phenolic phytochemicals from various cultivars of plums. Food Chem. 2003;81(3):321-6. doi: 10.1016/S03088146(02)00423-5.

22. Michel T, Destandau E, Le Floch G, Lucchesi ME, Elfakir C. Antimicrobial, antioxidant and phytochemical investigations of sea buckthorn (Hippophaë rhamnoides L.) leaf, stem, root and seed. Food Chem. 2012;131(3):754-60. doi: 10.1016/j.foodchem.2011.09.029.

23. Bors W, Michel C, Stettmaier K. Antioxidant effects of flavonoids. Biofactors. 1997;6(4):399-402. doi: 10.1002/ biof.5520060405.

24. Cornard JP, Merlin JC. Complexes of aluminium(III) with isoquercitrin: spectroscopic characterization and quantum chemical calculations. Polyhedron. 2002;21(27-28):280110. doi: 10.1016/S0277-5387(02)01288-3.

25. Grigoras CG, Destandau E, Fougere L, Elfakir C. Evaluation of apple pomace extracts as a source of bioactive compounds. Ind Crops Prod. 2013;49:794-804. doi: 10.1016/j.indcrop.2013.06.026.

26. Dafalla HAA. Studies on the constituents of Ficus capensis (Thunb). Pak J Soc Sci. 2005;3(5):751-4.

27. Feleke S, Brehane A. Triterpene compounds from the latex of Ficus sur I. Bull Chem Soc Ethiop. 2005;19(2):307-10. doi: 10.4314/bcse.v19i2.21137.

28. Muanda NF, Dicko A, Soulimani R. Chemical composition and biological activities of Ficus capensis leaves extracts. J Nat Prod. 2010;3(1):147-60. 